\title{
DROSHA Gene
}

National Cancer Institute

\section{Source}

National Cancer Institute. DROSHA Gene. NCI Thesaurus. Code C25955.

This gene plays a role in the processing of microRNA in the nucleus. 